\title{
Da'wah bi al-Hal in Empowering Campus-Assisted Community through Waste Bank Management
}

\author{
Mukti Ali* \& Saipullah Hasan \\ Institut Agama Islam Negeri Salatiga, Indonesia \\ *Email:muktiali@iaiansalatiga.ac.id
}

\begin{abstract}
As an institution of education and agent of social change, the Faculty of Da'wah, IAIN Salatiga, has Islamic religious characteristics. These characteristics confirm its missionary effort as a part of social responsibility. The Da'wah Faculty pursues empowerment by rolling out a program of waste bank management. This program is a manifestation of the application of da'wah bi al-hal (preaching by actuating) to build assisted-communities who are empowered and independent in processing garbage. Furthermore, the program of waste bank management not only provides clean and healthy communities but also increases the community's ability to gain environmental benefits and improving its economy. This study aims to analyze the implementation of da'wah movement through waste bank management, from assessment, recycling management, construction, to evaluation. The method of research in this study uses a qualitative method, Participatory Action Research (PAR) to make changes and benefits for the community, and empowerment theory as the mainframe of thought in carrying out da'wah bi al-hal. The results of participatory action research showed that preaching by actuating of Da'wah Faculty IAIN Salatiga in the assisted-communities has increased participation, trust, and cooperative relationships among them in managing the waste bank.
\end{abstract}

Keywords: da'wah bi al-hal, waste bank management, campus-assisted community

\begin{abstract}
ABSTRAK
Fakultas Dakwab IAIN Salatiga sebagai lembaga pemikiran dan agen perubahan sosial, memiliki karakteristik keagamaan Islam. Karakteristik ini menegubkan upaya berdakwah sebagai tanggung jawab sosialnya. Dalam melakukan dakwah di masyarakat, Fakultas Dakwah menempub cara pemberdayaan dengan menggulirkan program pengelolaan bank sampah. Hal ini sebagai wujud aplikasi dakwah bi al-hal untuk membangun masyarakat binaan yang berdaya dan mandiri dalam mengolah sampah. Program pengelolaan bank sampah tidak hanya memberikan manfaat lingkungan bersih dan sehat, tetapi juga meningkatkan kemampuan masyarakat untuk mengolah sampah dalam meningkatkan perekonomian. Penelitian ini bertujuan untuk menganalisis tentang implementasi dakwah bi al-hal dengan program pengelolaan bank sampah itu berjalan mulai assesment, manajemen daur ulang, pembangunan sarpras dan evaluasi. Metode dalam penelitian ini menggunakan metode kualitatif Participatory Action Research (PAR) untuk melakukan perubahan dan manfaat bagi masyarakat dengan teori pemberdayaan sebagai kerangka berfikir utama dalam melakukan dakwah bi al-bal. Hasil penelitian aksi partisipatif memperlihatkan bahwa sentuban pendampingan yang telah dilakukan Fakultas Dakwah IAIN Salatiga terhadap masyarakat binaannya dapat meningkatkan partisipasi, kepercayaan dan hubungan kerja sama diantara mereka dalam pengelolaan bank sampah.
\end{abstract} Kata kunci : dakwah bi al-hal, managemen bank sampah, masyarakat binaan kunci

Received: October 2019. Accepted: November 2019. Published: December 2020 


\section{INTRODUCTION}

Higher education, as reflected in the three pillars of higher education (Tridharma Perguruan Tinggi) has three pillars that cannot be separated and mutually reinforcing, namely education, research, and community service. The three pillars must be implemented simultaneously without being removed. If there is one missing from the tri dharma, then the implementation of the educational process in tertiary institutions will not go well.

Various ways and strategies are adopted by universities to optimize their duties. Community service is one form of Higher Education pillars besides education and research. This duty is following the mandate of Law Number 12, 2012 that "community service is academic community activities that utilize science and technology to advance the welfare of society and educate the nation's life" (Salahuddin, 2015, p. 3).

Community service is one of da'wah forms. Da'i (subject of da'wah), both as individuals and institutions, are required to have new knowledge, strategies, and methods in line with changes in society (Ghafur, 2014, p. 251). Preachers are not merely lecturers who are limited to various religious knowledge. Furthermore, the knowledge he conveyed must be able to encourage his people to improve their living conditions for the better. Preaching messages delivered should be able to inspire change in the face of various life problems or also called preaching bi alhal. According to Ma'arif et al. (2018, p. 2), da'wah bi al-hal is a method of empowering the community. Akhmad Sagir (2015, p. 17) further explained that the da'wah bi al-hal is an activity or an effort of humans to invite or call on other human beings for good. The contents of the invitation are al-khayr (virtue), amar ma'ruf nabyi munkar (command the good and forbid the bad).

Da'wah strategies that applied in the community must notice social conditions. Mubaligh (preachers), must be able to adjust the material and strategy to follow the social changes that occur (Amran, 2012, p. 77). The ability of preachers to understand the conditions of people's problems is conveyed and performed by needs. What is needed by the people is not based on the perception of preachers themselves, but based on the real conditions of community life. It is essential to conduct actual actions in line with the needed by recipients of da'wah (Sandi, 2017, p. 967).

In the process of $d a^{\prime}$ wab bi al-bal the community is not positioned as a passive object but as an active subject who can change his condition. Therefore, the message of preaching chosen in the process of preaching aims to trigger change because religion is not a passive element in the social process (Usman, 2012, p. 184).

One of the most common problems faced in society is waste management. Waste is often interpreted as goods or materials that are considered to be useless so that they never get proper management through the recycling process. 
(Mujahiddin et al. 2018, p. 105). Efforts to deal with waste problems are basically not just technical issues, but also in management aspects. For this reason, the solution is not limited to taking transport and disposing at the final location of the waste, but the management of waste reduction is done from the source, then the waste is sorted and recycled. The waste disposal-transport collection model is not yet a solution to the waste problem (Wulandari et al. 2017, p. 36). Waste management for sorting and recycling is known as waste bank management. The management concept of establishing a waste bank refers to Law Number 18 of 2008 concerning Waste Management and Government Regulation Number 81 of 2012 (Pratama \& Ihsan, 2017, p. 114). The law mandates the need for a fundamental paradigm shift in waste management, which is from the collectiontransport-disposal paradigm to the processing that relies on reducing waste and handling waste at its source (Suryani, 2014, p. 71-72). This, of course, requires active community participation in processing waste.

The Da'wah Faculty of IAIN Salatiga, as an institution education and agent of social change, has Islamic characteristics. These characteristics do not prevent the institution from collaboration with various parties. On the contrary, these characteristics can be used as an added value by this islamic institution to realize the da'wab bi al-hal in carrying out the teachings of Islam in the form of community service for social change.

Practicing the teachings of Islam requires a channel for da'wah. The practice of da'wah can be performed bi al-hal (by actions) and bi al-lisan (conveying religious knowledge). Preaching without being accompanied by corrective action is the weakest way. How to da'wah bi al-lisan in the form of lectures is a way that is often conducted (Jaya, 2007, p.65). The first and second ways are inseparable but carried out side by side to do good deeds towards the welfare of society. The Efforts to preach as said in motto "science with practicing, and practice with scient, and good deeds or thought, dhikr and pious deeds" relevant attached to the State Islamic Religious College (Mahmudi et al., 2008, p.6).

Community participation will encourage community empowerment in processing waste. Empowerment is done in the form of skills training to reduce, utilize, and recycle waste into products that have more value (Purba et al. 2014, p. 213). Philosophically, waste banks turn waste from problems into economic resources for everyone (Widiyanto et al. 2017, p. 386). Therefore, it is essential to build public awareness of waste management. Public awareness to participate actively in environmental cleanliness programs needs to be fostered and driven because a clean residential environment will not succeed if the community does not participate in achieving its goals (Ismawati, 2016, p. 60).

Waste Management through the waste bank program encourages waste producers to process waste through the $3 \mathrm{R}$ approach. The concept of Reuse, which is reusing rubbish that can still be used for other functions and the concept of recycle, namely recycling waste into new goods or products that are useful 
(Fadhilah and Naharin, 2017, p. 272). These three principles are carried out through smart, efficient, and programmed efforts (Maya et al., 2017, p. 158). Carrying out the recycling process by increasing participation in the waste bank program means growing recycling behavior (Selomo, 2016, p. 238).

The waste bank teaches the community to sort waste, to raise public awareness to process waste wisely so that it can reduce the waste that is transported to the landfill (Asteria and Heruman, 2016, p. 139). The waste bank acts as a facilitator, namely the role of a guide and assistant in providing education, facilitation, technology, and social networking. The role of the companion is significantly related to behavior change. In the context of community empowerment, the role of the companion is through socialization activities on waste segregation, training and education of crafts from waste, technical guidance on the financial management of waste sales results, and the provision of weighing tools for waste, brochures, pamphlets (Muhtadi, 2017, p. 192).

In response to the discourse of the development of da'wah in Islamic Higher Education, the Da'wah Faculty of IAIN Salatiga conducted the practice of proselytizing by rolling out a waste management program to develop a waste bank in the Wonolelo, Kadirejo Village, Pabelan, Semarang. From the results of the assessment, it was found that the problem that became the public's attention was that they did not yet have the skills to do waste management in the waste recycling process. Besides, the existence of a waste bank does not yet have adequate facilities and infrastructure. Currently, there has been no solution to this problem, making waste management challenging to develop in improving the standard of living of the community.

This study aims to analyze the implementation of preaching bi-ban in the waste bank management program ranging from assessment, recycling management, infrastructure development, and evaluation. Participatory action research on da'wah bi al-bal for handling waste problems in Indonesia is still rarely conducted. Some of the research that has been conducted previously is related to da'wah, including da'wah by community-based mosque empowerment, carried out in rural areas, and carried out by students. Research on preaching through the empowerment of mosque-based communities from the perspective of the Prophet's mission was carried out by Cucu Nurjamilah (2016). She noted that preaching in the form of mosque-based community empowerment has been played by Prophet Muhammad Saw. in the Medina Mosque. Forms of empowerment undertaken by the Prophet, in Nurjamilah's perspective, include empowerment in spiritual, social aspects (unity and equality), education, economics, politics, and defense. This empowerment is carried out by fostering the spiritual potential of community monotheism, providing access (social institutions) through the construction of mosques, peace agreements with various parties, the establishment of markets around mosques, the formation and training of defense forces, and security. 
The next study was conducted by Aliyudin (2016), who revealed da'wah bi al-hal through community economic empowerment in the Harja Mukti Village Banjaran, Majalengka. According to Aliyudin, the economic empowerment strategy undertaken by the Harja Mukti farmer group includes: making direct contact with the community to discuss issues and the public interest, demonstrating the results and the process of convincing the public, working with the government. The economic empowerment of the community is carried out through efforts to develop human resources, namely through various education and training activities.

Shobron, Rosyadi, \& Suaidy (2015) studies about proselytizing and empowerment to the economy of the community in Pesantren Walisongo Ngabar Ponorogo East Java in 2013-2014. The results of his research found empowerment models, namely: (1) empowerment of workers around pesantren, (2) empowerment of agriculture, (3) empowerment of cattle farms, (4) empowerment of public health, (5) empowerment of broadcasting and communication and (6) home business group empowerment.

Ahmad Faqih (2015) revealed in his research the preaching performed by students of the Islamic Community Study Program of the Da'wah and Communication Faculty of UIN Walisongo Semarang in mentoring waste care activities. Faqih found that efforts to increase the capacity of students' knowledge about waste management can be performed with the Participatory Rural Appraisal (PRA) method. Second, in the implementation of student capacity building programs with the PRA method, there will be a transfer of knowledge, transfer of value, and transfer of skills. Third, the program to increase the capacity of students to care about waste.

The difference with the research carried out by the Da'wah Faculty through community service activities is different from the previous studies above. This research uses the qualitative research method of Participatory Action Research (PAR). PAR is research that involves the active participation of relevant stakeholders in taking action based on their experience as a matter of making changes (Afandi, 2017, p. 38).

The reason for choosing PAR is because this research not only benefits researchers but also provides more significant benefits for the community. Suyanto (2017, p. 249) noted that PAR is considered more humane. The community is valued for its human dignity and dignity, not merely as objects of research. Communities are positioned as research subjects and active and creative actors in formulating programs and then implementing them to obtain benefits. In PAR, the primary measure of success is if the people involved feel that they are benefiting from the program (Wilmsen et al., 2008, p. 81). The application of proselytizing through participatory action research methods is not very popular among academics, especially universities in Indonesia. This research is important to deal with the garbage problem and the need for preaching in the future. 
In the context of proselytizing, it requires a humanist process between lecturers, students, and the community. They jointly conduct research, facilitation, and assistance to solve problems in the community based on their potential and abilities. It is essential to do so that the material and actions of preaching following community needs. Da'wah bi al-hal is an endeavor and commitment to providing benefits and changes that are desired together.

The application of $D a^{\prime} w a b$ bi al-hal in having the main mission of welfare and community empowerment is a demand or need for tertiary institutions, including Islamic religious tertiary institutions, to carry out contextual education and research processes in response to the development of social problems that occur in society (Hakim, 2017). Thus, education is not only thinking about the development of science at the campus level but also able to foster sensitivity, critical awareness to be directly involved in the actions of change in society.

Islamic factors, in this case, can strengthen empowerment efforts by providing a religious foundation for religious life. There is no doubt that Islamic teachings and values place a strong emphasis on the importance of humans having the responsibility to solve social problems in society.

\section{RESULT AND DISCUSSION}

\section{Profile and History of Waste Bank}

The waste bank, which is the location of this research, is located in 19th neighbbourhood (RT), 6th hamlet (RW) Wonolelo Village, Kadirejo, Pabelan, Semarang, Central Java. The idea of a waste bank that founded in 2011 began when there was a meeting of the Hope Family Program (Program Keluarga Harapan/PKH), which was held routinely once a month. When the PKH program took place, a social worker named Yusron, who was a guest speaker, often saw the behavior of residents who throw garbage in the community area. Yusron then provided input to the community to maintain cleanliness through the waste bank. Furthermore, he said that the function of the waste bank is not only to clean up the residential environment but also to increase people's income.

Seeing the enthusiasm of residents who want to learn, Yusron provides special assistance about what a waste bank is, how it works and its benefits for the community. The assistance provided is not just the delivery of material but also accompanied by practice directly to collect and sort the waste. The selected waste is subsequently deposited to the waste bank for sale. The price of waste considering to the type of waste. The Environment Agency of Semarang accompanied the marketing of waste sales in collaboration with collectors.

The establishment of a waste bank did not take place quickly. There are several obstacles in the process of building public awareness about the importance of maintaining cleanliness and environmental sustainability of the settlement. Some residents are proud and ashamed to mingle with garbage. Activities, such as 
picking up trash and collecting it, can make the body dirty and embarrassing like a scavenger. This shame and prestige affect several members of the waste bank who do not want to deposit the waste bank and then choose to commend it to their neighbors.

Knowing this condition, the management of the waste bank then approached and gave awareness to the residents so that they would return to being active in promoting the waste bank. Not only the residents concerned, the management of the waste bank also met face to face and had a dialogue with people who were known to influence the residents often to stop doing the waste bank activities. As a result, the management of the waste bank managed to resuscitate residents who were initially affected by sedition and then realized that the activity of managing waste was not an embarrassing activity but instead a noble job to maintain environmental cleanliness.

The existence of a waste bank is considered to provide significant benefits for the community. It can be seen from the positive changes that can be perceived from environmental conditions and community settlements (Fadhilah \& Naharin, 2017). They feel a cleaner environment, more beautiful looking settlements. More than that, a clean environment from garbage prevents people's lives from the threat of catastrophic floods that often occur during the rainy season. Before a waste bank built, there was trash scattered around the streets and homes of residents, and then during the rainy season, the garbage flowed and clogged the drainage water. As a result, flood disasters often occur because the drainage water flow becomes obstructed and flooded the residential areas.

The waste bank officially established in 2017 with a decree (SK) from the village government Number: 141/15 / IX / 2017. The structure of the severity of the Mandiri Muda waste bank in 19/06 Wonolelo Village of Kadirejo consist of Chairperson: Qibtiyah, Deputy Chairperson: Titik Handayani, Secretary: Naimah and Syafaah, Treasurer: Yantiyem and Badriyah, Public Relations Division: Priyati and Istiqomah, Coordination Division: Nur Kotimah and Siti Rohmah, and Sales Coordinator Division: Suparwi and Surati.

The establishment of the waste bank program is part of the da'wah activities. Da'wah is an essential form of a communication tool to convey the message of Islam to the public (Baharudin \& Ismail, 2016) As a means of propaganda, and communication plays an important role in calling for goodness by carrying out the teachings of sharia religion. Appeals and invitations conveyed by preachers certainly must be easily understood by the people and then applied in everyday life.

In this case, the role of the preacher will be very important because he becomes a role model for his people in the field of religious life. Every word and deed will be an example and imitated by the congregation. Therefore, what he said must be in accordance with his actions. If not, then a preacher will lose his social function and eventually will be abandoned by his congregation. In the Qur'an 
(Surah Al-Fushilat [5]: 33), "it is stated that preaching is the best words and deeds. people, who surrender themselves?"

\section{Waste Management}

Waste management in banks has certain advantages compared to waste management models in collectors. In the garbage, the bank accepts all types of waste, both organic and non-organic, to be processed into use and economic value. Unlike selling garbage to collectors, only accept certain types of waste that can be exchanged for money. Traders do not accept rubbish from broken glass, mica, cigarette packs, and other items, but in the waste bank, all of that can be money.

The experience of one of the waste bank members was once offered an offer to sell used drinks to collectors at a higher price, but collectors did not want to buy all the garbage and secondhand goods. All management of the waste bank has rejected this offer of cooperation because the purpose of the waste bank is not only to seek higher profits but, more importantly, to cleanliness and environmental health of the community.

Figure 1 Waste Bank Work Flow

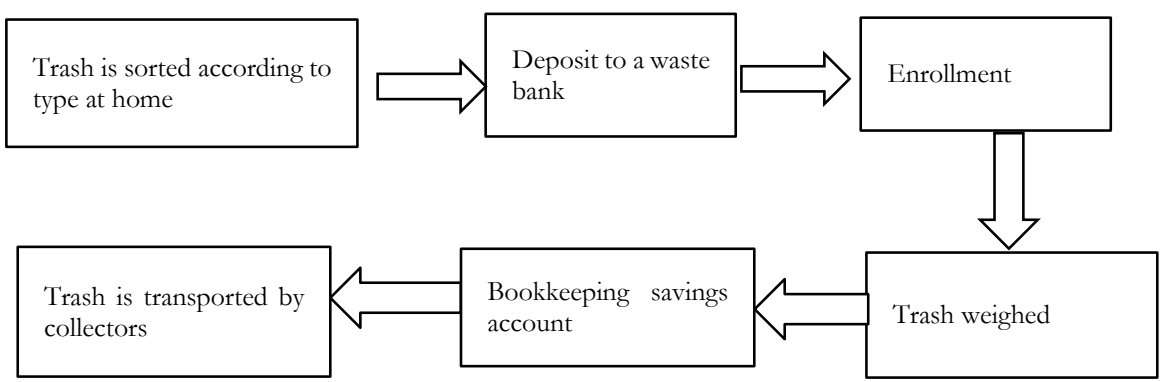

Based on observations, as shows in Figure 1, the activities of waste bank in sorting and collecting waste look neater and cleaner compared to the garbage managed by collectors and waste bosses that look like mounting garbage so that cleanliness and beauty are less noticed. Cleanliness that always maintained in a waste bank makes residents comfortable and happy to participate in all activities held.

The existence of a waste bank is not only beneficial for environmental cleanliness but can also increase people's income. A series of waste bank activities are waste sorted by the type at home, then waste deposited to the waste bank, customers hand over waste in the bank, the waste is weighed and valued according to its type, money is received, recorded in a savings book, and finally the garbage is transported by collectors. The waste bank workflow can be seen in the above workflow chart in Figure 1. 
The management will manage the proceeds of receiving money from customers into savings, social funds, and recreation. Customers who have savings will receive their savings once a year. Social funds intended for compensation funds given to each member who suffered an accident, such as death. While the recreational funds used for entertainment and pilgrimage activities. Moreover, the education funds used for comparative study activities, hygiene competitions, and others.

This sorting and collecting waste activity has been going on for a long time since the waste bank established in 2013. The community in Wonolelo Village has an environmentally friendly habit always to instill the value of cleanliness in daily life. Activities that take place for a long time form an institutionalized activity in the social system of the community. Waste bank management activities become shared knowledge that encourages the emergence of social movements spearheaded by women to love the environment and make changes for the better. The knowledge and movement of environmental love eventually formed a rule and culture adopted by the community.

Waste management activities are not only carried out in the waste bank learning space, but the community is consciously responsive to managing waste in social and religious activities. Waste management activities are recognized from some community gatherings and activities, such as recitation and others. After the program, waste such as plastic, bottles, glass, mica, and paper are taken together and collected and brought to their respective homes to deposit to the waste bank. This environmentally friendly activity has become routine and institutionalized in the social system of the community.

\section{Steps in Participatory Action Research}

The steps of the Participatory Action Research (PAR) carried out in this study correspond to the opinion of Agus Afandi (2017) as follows: first, Preliminary mapping. The initial mapping conducted by researchers was to determine the location of the study in Wonolelo Village, Kadirejo, Pabelan, Semarang. The women's community welcomed the presence of researchers during the community gathered in the waste bank container. The first time researchers were received by Umi, as chairman of the waste bank. This warm reception and welcome from the community made it easy for researchers to be accepted and be part of the Wonolelo community members.

The researcher also met with many religious leaders, community leaders, and the village government to ask permission and input so that research and community empowerment can later run well and bring benefits for better social change in the community. Involvement of religious leaders, community leaders, and known as a key person that will facilitate researchers in carrying out research agendas and empowerment programs that are appropriate to the needs of the local community. 
Second, Building Humanitarian Relations. At this stage, researchers conduct inculturation in order to build trust (trust-building) with the community. The steps taken are mingling with the community, gathering to religious leaders, community leaders, and the government. Various inputs given to researchers, including empowerment activities carried out on an ongoing basis, schedule of activities to adjust the activities of citizens, maintain religious and ethical norms, and other input.

Building human relations is also conducted at the time of research by involving themselves in participating in daily activities in the community. For example, engaging in community work activities, prayer congregants, routine waste bank meetings, and community service. These ways are deemed adequate for establishing approaches and figuring out problems and needs in designing community empowerment programs.

Third, Determination of Research Agenda for Social Change. Determining the research agenda is carried out in a participatory manner by involving oneself and learning to understand the conditions of people's lives. Research conducted is not just to find out the meaning of social reality but to make social changes in providing more significant benefits for the betterment of society.

Fourth, participatory mapping. Mapping research is conducted by involving the participation of the community in formulating empowerment program planning to suit the community's problems and needs. The results of the mapping show that Wonolelo Village has a conscious culture of managing waste collected in a waste bank container. In this mapping activity, researchers, together with residents, together with identify problems, needs, and resources to find out opportunities for solving problems and developing their potential. It is important so that people can see their abilities and solve their problems without relying on the help of others. The researchers play a role as a facilitator in helping the community solve the problems at hand.

Fifth, Formulate Humanitarian Problems. Research activities carried out with the community present problems finding, including (1) management, and members of the waste bank do not yet have the skills to process waste into crafts. The lack of garbage crafts skills also has an impact on the slow change in progress at the waste bank. For example, a waste bank does not meet the requirements to collaborate and apply for infrastructure and facilities in the Government of the Environment Agency (Dinas Lingkungan Hidup). the Government of the Environment Agency accepted the submission of cooperation and assistance in facilities and infrastructure when the community meets the requirements. Some of the requirements are: having an organizational structure, having a decree from the village government, having an office and warehouse collecting garbage, implementing the $3 \mathrm{R}$ principle, owning handicraft products and possessing machine technology waste processor. 
The second problem faced by waste banks is that they do not yet have the facilities and infrastructure as a place to collect and store garbage before sold to collectors. As a result, garbage collection locations are often unable to collect garbage from residents so that it looks untidy and disrupts the activities of residents whose homes are made of landfill.

Sixth, Develop a Movement Strategy, Organize Resources, or Potential. The formulation of a movement strategy involves the involvement of relevant stakeholders. Researchers approached the management and members of the waste bank, religious leaders, community leaders, village government, students, and faculty of the Islamic Missionary School Salatiga. Empowerment efforts that will be carried out, it is not possible for the researchers to conduct it unless various elements of interest for the welfare of society. Each stakeholder will contribute and play a role in efforts to succeed in community empowerment programs.

Organizing resources or potential by mapping natural resources and human resources. Human resources by utilizing the skills of students to recycle waste into crafts. In addition to students, lecturers also involve themselves in conducting research and mentoring efforts needed by the community. More than that, the da'wah faculty of IAIN Salatiga also contributed by providing financial assistance for the development of waste bank facilities and infrastructure. The participation of students, lecturers, Da'wah Faculty, and the community is vital for community empowerment.

The change action is also carried out by holding various activities involving the parties concerned to take roles and contribute to community empowerment. The change actions taken are (1) providing learning and practice of recycling waste into economic value crafts, (2) Building waste bank facilities and infrastructure, and (3) building relationships with study tours.

The presence of a waste bank does not only provide changes to environmental cleanliness but also provides economic and public health benefits. The touch of assistance in managing the waste bank has increased the participation and skills of the community, especially women, in applying the principles of Reduce, Reuse, and Recycle (3R). These three principles have become an institutionalized routine in managing environmental problems around them.

\section{Waste Recycling Assistance}

Assistance activities by Da'wah Faculty of IAIN Salatiga were carried out by establishing a waste recycling school. It is intended that waste management is carried out based on the principle of Reduce, Reuse, and Recycle (3R). These three principles have not been implemented thoroughly and are focused on reducing and reuse. The absence of waste recycling management has an impact on the slow progress of change in the waste bank. For example, a waste bank does not meet the requirements to collaborate and apply for infrastructure and facilities 
in the Government of the Environment Agency. Submission of cooperation and assistance in facilities and infrastructure can be accepted by the Office of the Environment as long as the community meets the following requirements (1) has an organizational structure (2) a decree from the village government (3) has an office and warehouse to collect garbage (4) implements the $3 \mathrm{R}$ principle (5) own waste handicraft products (6) have waste processing machine technology.

Waste recycling activities are carried out by learning and practicing making innovation and creativity of the community to make present-day waste products such as bags, wallets, fruit baskets, plates, fashion show clothes, tablecloths, and other products. This activity takes place in a waste bank office and is carried out continuously, and there is no time limit specified. This activity will be carried out until the community can make their products. The evaluation results of this activity show that some waste bank customers can make and market products through exhibitions that are routinely held by the environmental department.

Another benefit felt by the community from this activity is helping the waste bank in participating in competition competitions and proposing cooperation with involved governments. If there is a clean environmental competition, the field officers will ask the management of the waste bank if they have garbage handicraft products. The skills and products shown by the waste bank can help add value to win cleanliness competition.

The Waste Bank is an institution that is present amid people's lives to manage waste by applying the principles of reducing, reusing, and recycling. These three principles are implemented well if they involve community participation. Participation can encourage a joint movement to care and love the environment. A love for the environment needs to be developed so that the community is truly voluntary and aware of protecting the environment. A clean environment will make the community relatively healthy so that it has resilience in the health sector.

Maintaining environmental sustainability is aimed at meeting the needs of today's society and future needs. Human activities that pay attention to the environment can maintain environmental sustainability in the future, and vice versa. Therefore, the community's concern in protecting the environment is also our concern for the sustainability of the lives of future generations.

\section{Providing Assistance for the Development of Facilities and Infrastructure} On September 21, 2019, the Salatiga IAIN Da'wah Faculty conducted a community service program in Wonolelo Village, Kadirejo, Pabelan, Semarang. This activity was themed "Community Service and Empowerment in Waste Bank Management."

There is a change of perspective in the Da'wah faculty that community service is often conducted in educational institutions such as schools and Islamic boarding schools, now that view has changed. Community service activities are carried out interacting and dialogue in formulating programs that are appropriate 
to the problems and needs of the community. This activity involves the participation of students and lecturers by going directly to the village. The students and lecturers have the spirit and commitment to carry out community service in carrying out the tri dharma of higher education.

The participants who attended the event were from the head of the KWT, management, and members of the waste bank, all of whom were women. While the lecturers who were present were from the deputy dean for student affairs and cooperation, the head of the Department of Development of Islamic society (Pengembangan Masyarakat Islam), and lecturers. Activities take place by way of dialogue to listen to people's complaints about the problems faced. During the discussion, it was found that several problems did not have the facilities and infrastructure; the Da'wah Faculty would provide stimulant funding of Rp. $2,000,000.00$. The provision of this assistance aims to encourage the community to be able to organize together in building facilities and infrastructure. The participants calculated the estimated construction of facilities and infrastructure costing Rp. 5,000,000.00. the management of the waste bank has finally agreed with the shortfall in costs to be borne by self-help. On October 5, 2019, students and residents jointly built the facilities and infrastructure.

\section{Building Collaboration for the Care Environmental Movement}

Efforts to create a care environmental movement by organizing and processing waste are not carried out by the community of the waste bank itself, but rather they involve the participation of various interested parties. Those who involved in this movement were religious leaders, village authorities, environmental services, and the Salatiga IAIN Da'wah Faculty.

The environmental love movement was born driven by a shared sense of environmental problems around them. Women's sensitivity arises because the daily activities of the community in Wonolelo Village produce waste. The existence of waste is considered something that has no use-value so that waste cannot be adequately managed. People's behavior in treating waste by burning, throwing away, and being buried. These methods have a bad impact on people's lives both in terms of the environment and health. Littering behavior makes the environment and residential areas dirty. The behavior of burying trash makes the soil damaged and cannot be planted. Garbage burning behavior has an impact on decreasing the quality of health. Ibu Handayani said that her child had a lung problem with shortness of breath due to frequent inhalation of plastic waste and neighbor's baby diapers.

The strategy of the environmental love movement involves the involvement of relevant stakeholders. The waste bank manager involves the participation of religious leaders, the village government, the Salatiga IAIN Da'wah Faculty, and the Semarang Environment Agency. Each stakeholder contributes and plays a role in efforts to succeed in the welfare of society. 
Religious leaders play a role in providing religious knowledge that fosters public awareness to preserve the environment. The involvement of religious leaders is essential because they are community role models. Examples of their environmentally friendly behavior will encourage people to practice the same thing.

The village government provides legality in the form of issuing a decree on the establishment of a waste bank. Thus, the status of the institution has gained recognition from the government. Besides, the village government also provides facilities and infrastructure such as sewing machines, tables, and other tools that support the process of making waste into handicrafts.

The Faculty of Da'wa IAIN Salatiga assists the manager of the waste bank to make contemporary handicraft products to encourage community creativity in the process of recycling waste. As a result, the manager of the waste bank already has several handicraft products such as bags, flower designs, tablecloths, plates, and fruit baskets. On September 26, 2019, the Da'wah Faculty assisted in the amount of Rp. 2,000,000.00 to establish waste bank facilities and infrastructure.

Related governments like the Office of the Environment Agency have assisted in the development of the waste bank business. The office helps market waste in collaboration with collectors and waste management factories. The office government also provides an opportunity for waste banks to propose assistance in the construction of facilities and infrastructure (facilities and infrastructure).

Semarang environmental service assists by inviting the participation of waste bank managers to participate in various moments of environmental love activities such as exhibitions, cleaning competitions, and comparative studies. This assistance is intended to increase knowledge, skills, and expand social networks. The environmental love movement has fostered trust and a network of cooperation between the community, government, and universities. Each role and contribute following its capacity.

\section{Implementation of Da'wah Bi al-hal in Waste Management}

This da'wah was formulated with several steps, including the first, by formulating Da'wah Community. The Da'wah Faculty formulated the waste bank community in Wonolelo Village as a target for da'wah. The presence of the assistance team amid the community was welcomed by the community gathered in the waste bank container.

Second, Setting Goals. The purpose of preaching to be carried out is to carry out community service by way of da'wah bi al-hal in waste management to form a community of preaching faculty.

Third, Compile Da'wah Message to be Delivered. Success in da'wah will be determined by the issue or problem of public concern. The selection of issues is carried out with a need assessment to determine the needs of the community. The results of the assessment present the findings of the community of waste banks 
that do not have good management, starting from the lack of waste recycling skills and do not have adequate facilities. Therefore, the message of preaching was compiled and delivered aims to increase the capacity of the community in managing the waste bank.

Choosing the Right Method for Delivering Da'wah Messages The selection of methods is the implementation phase of the message selection mechanism. The process of delivering da'wah messages is performed by interaction and dialogue with the community. The companion team consisted of lecturers, and students came down to the community by involving themselves to find out what the desired needs were. In the process of da'wah, the community is an active subject who could express their complaints and opinions about the lives problem and how to solve them. The process of delivering da'wah is also carried out by mapping techniques (mapping) to find out the picture of the future dreams of the community.

Fourth, the Implementation of the Evaluation Program (change). Implementation of the program is carried out by holding various activities, namely (1) assisting recycling of waste into handicrafts of economic value (2) providing stimulant assistance (3) Building facilities and infrastructure for waste banks (4) building relationships and study tours.

Table 1. Schedule of Guidance Materials

\begin{tabular}{|c|c|c|}
\hline Variable & Indicator & Target \\
\hline \multirow{4}{*}{$\begin{array}{l}\text { Improving } \\
\text { the standard } \\
\text { of living of } \\
\text { the people }\end{array}$} & $\begin{array}{l}\text { Improved waste recycling } \\
\text { skills }\end{array}$ & $\begin{array}{l}\text { Able to make waste material products such as } \\
\text { bags, wallets, fruit containers, plates, clothes } \\
\text { and tablecloths. }\end{array}$ \\
\hline & Improved economy & Increased revenue \\
\hline & Increased marketing access & $\begin{array}{l}\text { Increasing orders and marketing through } \\
\text { exhibition events or the like held by the } \\
\text { environmental service }\end{array}$ \\
\hline & $\begin{array}{l}\text { Availability of physical } \\
\text { facilities and infrastructure }\end{array}$ & $\begin{array}{l}\text { The condition of the location of the garbage } \\
\text { collection becomes neater and cleaner }\end{array}$ \\
\hline \multirow{4}{*}{$\begin{array}{l}\text { Level of } \\
\text { stakeholder } \\
\text { participation }\end{array}$} & Stakeholder involvement & $\begin{array}{l}\text { The role of lecturers and students in providing } \\
\text { assistance }\end{array}$ \\
\hline & & $\begin{array}{l}\text { the presence of a waste bank member in the } \\
\text { discussion }\end{array}$ \\
\hline & & $\begin{array}{l}\text { increasing citizen participation in the } \\
\text { construction of facilities and infrastructure }\end{array}$ \\
\hline & & $\begin{array}{l}\text { there is criticism, input or feedback on the } \\
\text { improvement of assistance services }\end{array}$ \\
\hline
\end{tabular}




\begin{tabular}{lll}
\hline Variable & Indicator & \multicolumn{1}{c}{ Target } \\
\hline $\begin{array}{l}\text { The intensity } \\
\text { of media } \\
\text { coverage }\end{array}$ & $\begin{array}{l}\text { frequency of media } \\
\text { coverage } \\
\text { - a variety of media reviews }\end{array}$ & $\begin{array}{l}\text { Mentoring activities are posted on the da'wah } \\
\text { faculty website and national online media } \\
\text { forms of coverage such as hard news }\end{array}$ \\
$\begin{array}{l}\text { Improved } \\
\text { learning } \\
\text { network }\end{array}$ & Increased learning network & $\begin{array}{l}\text { The Da'wah Faculty has a built community } \\
\text { The fostered community becomes a study tour } \\
\text { by the Forkomasi (PMI student } \\
\text { communication forum) at Central Java and } \\
\text { DIY levels }\end{array}$ \\
$\begin{array}{l}\text { Increased } \\
\text { social capital }\end{array}$ & $\begin{array}{l}\text { Increased cooperation and } \\
\text { trust }\end{array}$ & $\begin{array}{l}\text { Increased cooperation and trust relationships } \\
\text { between the Da'wah faculty and the waste bank } \\
\text { community }\end{array}$ \\
$\begin{array}{l}\text { Da'wah } \\
\text { intensity }\end{array}$ & $\begin{array}{l}\text { Quantity of da'wah recipient } \\
\text { The quality of the preaching } \\
\text { recipient }\end{array}$ & $\begin{array}{l}\text { Participants who participated in the mentoring } \\
\text { activities were between 25-30 } \\
\text { Da'wah model with dialogue and problem } \\
\text { solving actions }\end{array}$ \\
\hline
\end{tabular}

The waste management program carried out by the Da'wah faculty has an impact on the changes described in the conditions before and after the mentoring is carried out as shown in Table 1.

\section{CLOSING}

The results of this participatory action research concluded that the preaching conducted by the Da'wah Faculty of IAIN Salatiga showed evidence of success and benefits to the community in managing waste independently and sustainably. Waste bank managers who were previously passive and dependent currently can develop creativity to develop their skills and build facilities and infrastructure in a self-supporting way that has been their expected. Assistance programs, or assisting with the da'wah approach, has been an effective way to carry out community service that is in line with the needs of da'wah participants. Through da'wah bi alhal, it is essential to know how people respond to the ideas of change in building trust and cooperation by practicing Islamic values.

\section{BIBLIOGRAPHY}

Afandi, A. et al.. (2017). Modul Riset Transformatif. Jakarta: Dwi Putra Pustaka Jaya. Aliyudin (2016). Dakwah bi al-Hal melalui Pemberdayaan Ekonomi Masyarakat. AN-NID A: Scientific Journal for Da'wa Studies. 15(2) 187-206 Retrieved from https://journal.uinsgd.ac.id/index.php/anida/article/view/1168 Amran, A. (2012). Dakwah dan Perubahan Sosial. Jurnal Hikmah. 6(01), 68-86 Asteria, D. \& Heruman, H.(2016). Bank Sampah Sebagai Alternatif Strategi 
Pengelolaan Sampah Berbasis Masyarakat Di Tasikmalaya. Jurnal Manusia dan Lingkungan. 23(1), 136-141

Ahmad, M., Toto, R., \& Roem, T. (2008). Gamang Lembaga Pendidikan Islam Menghadapi Perubahan Sosial. Jakarta: Departemen Agama Republik Indonesia.

Baharudin, N. A., \& Ismail, A. S. (2016). Architectural Style of Da'wah Mosque in Malaysia: from Vernacular to Modern Structures. International. Journal of Built Environment and Sustainability, 3(2). DOI: 10.11113/ijbes.v3.n2.122

Fadhilah, N \& Naharin, N. (2017). Perempuan dan Konservasi Lingkungan: Studi Bank Sampah Berlian Malang Jawa Timur. Jurnal Al-Tahrir, 17(2), 269-288. Retrieved from http:/ /jurnal.iainponorogo.ac.id/index.php/tahrir/article/view/1023

Faqih, A. (2015) Penguatan Kapasitas Mahasiswa Peduli Sampah (Pendampingan Mahasiswa Prodi Pengembangan Masyarakat Islam (Pmi) Fakultas Dakwah Dan Komunikasi UIN Walisongo Semarang) 15(1) Dimas: Jurnal Pemikiran Agama untuk Pemberdayaan. Retrieved from http://journal.walisongo. ac.id/index.php/dimas/issue/view/134

Ghafur, W. A. (2014). Dakwah Bil-Hikmah di Era Informasi dan Globalisasi Berdakwah di Masyarakat Baru. Ilmu Dakwah: Academic Joumal for Homiletic Studies. 34(2), 236-258. Retrieved from http://journal.walisongo.ac.id/ index.php/dakwah/article/view/69

Hakim, R. (2017). Dakwah Bil Hal: Implementasi Nilai Amanah dalam Organisasi Pengelola Zakat untuk Mengurangi Kesenjangan dan Kemiskinan. Jurnal Ekonomi Syariah. 2(2), 42-63. Retrieved from https://journal.lppmunasman.ac.id/index.php/jikm/article/view/156

Ismawati, A. (2016). Gambaran Partisipasi Masyarakat dalam Pengelolaan Sampah Pada Bank Sampah UKM Mandiri di RW 002 Kelurahan Tamamaung Kecamatan Panakkukang Kota Makassar. Jurnal Kesehatan Masyarakat. 2( 2), 2541-4542. Retrieved from https://journal.lppmunasman.ac.id/index.php/jikm/article/view/156

Jaya, P. H. I. et al.. (2007). Model-model Kesejabteraan Sosial Islam Perspektif Normatif Filosofis dan Praktis. Yogyakarta: LkiS.

Nurjamilah, C. (2016), Pemberdayaan Masyarakat Berbasis Masjid dalam Perspektif Dakwah Nabi Saw. Journal of Islamic Studies and Humanities 1(1). 93-119. DOI: $10.21580 /$ jish.11.1375

Ma'arif, B. S., Parihat, Y. \& Umar, S. (2018). Persuasive Da'wah Activities and the Socio-Demographic Factor. Atlantis press Advances in Social Science, Education and Humanities Research, Vol. 307. Retrieved from https://www.atlantis-press.com/proceedings/sores-18/55915271

Mahmudi, et al. (2008). Gamang Lembaga Pendidikan Islam Menghadapi Perubahan Sosial. Jakarta: Departemen Agama Republik Indonesia.

Maya, S, Sugeng, H. \& Umi, K. (2017). Pemberdayaan Masyarakat Melalui 
Pengelolaan Sampah Menjadi Nilai Ekonomis dan Pembentukan Bank Sampah di Kelurahan Tanjung Barat. Proceeding of Community Development. 1. 158-161. Retrieved from https://zenodo.org/record/ 1148876\#.Xqq66pmyTIU

Muhtadi. (2017). Pendampingan Bank Sampah Melati Bersih Berbasis Pemberdayaan Bagi Masyarakat Urban. Jurnal Pemberdayaan Masyarakat, 1(2), 187-204. Retrieved from http://ejournal.uin-suka.ac.id/dakwah/JPMI/ article/view/1134

Mujahiddin, T. Y., \& Efendi, A. (2018). Analysis of the Effect of Waste Bank Program on Empowerment of Poor Women in Kelurahan Sicanang Belawan Medan. Budapest International Research and Critics Institute-Journal (BIRCI-Journal) 1(3), 105-113. Retrieved from http://bircujournal.com/index.php/birci/article/view/34

Pratama, R. A. \& Ihsan, I. M. (2017). Peluang Penguatan Bank Sampah untuk Mengurangi Timbulan Sampah Perkotaan Studi Kasus: Bank Sampah Malang. Jurnal Teknologi Lingkungan. 18(1), 112-119. Retrieved from http:// jurnal.bppt.go.id/index.php/JTL/article/view/1743

Purba, H. D., Meidiana, C. \& Adrianto, D. W.(2014). Waste Management Scenario through Community Based Waste Bank: A Case Study of Kepanjen District, Malang Regency, Indonesia. International Journal of Environmental Science and Development, 5(2). Retrieved from http:/ $/$ www.ijesd.org $/$ index.php? $\mathrm{m}=$ content $\& \mathrm{c}=$ index $\& \mathrm{a}=$ show\&catid $=5$ 0\&id $=786$

Sagir, A. (2015). Dakwah bi al-hal: Prospek dan Tantangan Da'i. Alhadharab: Jurnal Ilmu Dakwah. 14(27) 1-13. Retrieved from https://jurnal.uinantasari.ac.id/index.php/alhadharah/article/view/1224

Salahuddin et al. (2015). Panduan KKN ABCD UIN Sunan Ampel Surabaya Asset Based Community-driven Development ( $A B C D)$. Surabaya: LP2M UIN Sunan Ampel.

Sandi, F. A. (2017). Dakwah Bi al-hal: Muhammadiyah Strategy In The Empowerment of Disabilities Groups In Yogyakarta. IJASOS-International E-Journal of Advances in Social Sciences, 3(9). Retrieved from http:/ / nias.muhammadiyah.or.id/download-reference-aboutmuhammadiyah-1239.html

Selomo, M. et al.. (2016). Bank Sampah Sebagai Salah Satu Solusi Penanganan Sampah di Kota Makassar. Media Kesehatan Masyarakat Indonesia, 12(4) 232240, Retrieved from http://journal.unhas.ac.id/index.php/mkmi/article/ view/1543

Shobron, S., Rosyadi, I. Suaidy, M. Z. (2015) Dakwah bi al-hal Pesantren Walisongo Ngabar Ponorogo Jawa Timur dalam Pemberdayaan Ekonomi Masyarakat Tahun 2013-2014. Profetika 16(1). 1-24. Retrieved from http://journals.ums.ac.id/index.php/profetika/article/view/179 
Suryani, A. S. (2014). Peran Bank Sampah dalam Efektivitas Pengelolaan Sampah (Studi Kasus Bank Sampah Malang) Jurnal Aspirasi. 5(1), 71-84. Retrieved from https://jurnal.dpr.go.id/index.php/aspirasi/article/view/447

Suyanto. (2018). Membangun Kesadaran Sodaqoh Sampah Sebagai Model Pemberdayaan Masyarakat. Jurnal Pemberdayaan Masyarakat: Media Pemikiran dan Dakwah Pembangunan, 1(2), 245. DOI: 10.14421/jpm.2017.012-02

Usman, S. (2012). Pembangunan dan Pemberdayaan Masyarakat. Yogyakarta: Pustaka Pelajar.

Widiyanto, A. F. \& Rahab (2017). Community Participation in Bank of Garbage: Explorative Case Study in Banyumas Regency. Jurnal Kebudayaan dan Politik. 30(4), 367-376. DOI: 10.20473/mkp.V30I42017.367-376

Wilmsen, C. et al.. (2008). Partnerships for Empowerment Participatory Research for Community-based Natural Resource Management. The UK and USA: Earthscan.

Wulandari, D., Utomo, S. H., \& Narmaditya, B. S. (2017). Waste Bank: Waste Management Model in Improving Local Economy. International Journal of Energy Economics and Policy, 7(3), 36-41. Retrieved from https://www.econjournals.com/index.php/ijeep/article/view/4496 